\title{
URBAN RENEWAL: ACQUISITION OF REDEVELOPMENT PROPERTY BY EMINENT DOMAIN
}

$U_{\text {RBAN RENEWAL programs }}{ }^{1}$ are rapidly changing the face of American cities. Forty-five states and the District of Columbia now have enabling legislation designed to allow municipalities to qualify for the liberal federal financial assistance necessary to undertake such programs. ${ }^{2}$ Most of the projects undertaken to date involve the redevelopment of slums and blighted areas. Redevelopment projects $^{3}$ basically involve three phases: planning; land acquisition and clearance; and disposition of the cleared land to private developers who rebuild the area according to a comprehensive plan. This comment will explore some of the recurring problems involved in the acquisition of property by eminent domain for these projects.

The law of eminent domain plays a central role in the success of a redevelopment project. Once the plan is approved, large tracts of urban land, many of which are intensely developed, must be acquired quickly and efficiently $y^{4}$ in order that they may be cleared and

${ }^{1}$ See generally Sogg \& Wertheimer, Urban Renewal: Problems of Eliminating and Preventing Urban Deterioration, 72 HARv. L. REv. 504 (1959); Urban Renewal (pts. 1-2), 25 LAW \& CoNTEMP. PRoв. 631 (1960), 26 Id. I (1961); Urban Renewal Symposium, 21 FED. B.J. 269 (1961).

' Up to two-thirds of the money needed for a project comes from federal loans and grants. Federal financial aid was first made available by Title $I$ of the Housing Act of 1949, 63 Stat. 413 (1949), as amended, 42 U.S.C. $\$ \$ 1450-64$ (Supp. IV 1962). For analysis of the federal legislation, see Foard \& Fefferman, Federal Urban Renewal Legislation, 25 LAw \& CONTEMP. PROB. 635 (1960); Johnstone, The Federal Urban Renewal Program, 25 U. CHI. L. REv. 301 (1958). For analysis of the 1961 amendments, see Bryant, Federal Renewal Legislation-1961, 21 FED. B.J. 284 (1961).

${ }^{3}$ Redevelopment is only one of several types of programs eligible for federal aid under urban renewal legislation. Rehabilitation, conservation and reclamation programs are some of the others. A single project may include a combination of several of these programs. For definitions of these terms, see Johnstone, supra note 2, at $301 \mathrm{n} .2$.

"Ordinarily, land acquisition will not begin until after final approval of the project by the Housing and Home Finance Agency [hereinafter cited as HHFA], culminating in the signing of a Loan and Grant Contract. The federal loans from this contract are the main source of funds for land acquisition. Although most state enabling acts prohibit the acquisition of land before final approval of the plan by the governing body of the city, see, e.g., N.C. GEN. STAT. $\$ 160-463$ (c) (Supp. 1961), a few statutes allow acquisition before approval of a project if a general redevelopment plan for the whole city exists. See, e.g., Conn. Gen. STar. ANN. \$ 8-128 (1960). Under certain circumstances, the HHFA will provide loan funds for this earlier acquisition. HHFA URban ReNewal MaNual $\$ 13-1$ (1960) [hereinafter cited as Urban ReNEwal Manual]. 
made ready for sale or lease to private developers. 5 Since many landowners are unwilling to sell for the price offered ${ }^{0}$ by the local planning agency much of the land in a project area must be acquired by condemnation proceedings.

Eminent domain proceedings are at best cumbersome and timeconsuming. Always present is the possibility that a court decision may invalidate actions taken in the planning phase of a project long after the plan has been approved.8 Even where there has been compliance with the prerequisites for a valid taking, the antiquated eminent domain statutes existing in most states inordinately delay the vesting of title in the local planning agency. In many instances, an agency enters into contracts with developers while proceeding to acquire project property. Protracted eminent domain proceedings present the danger that an agency will have to default in these contracts because it cannot deliver title to contested property within the specified time. ${ }^{9}$ Furthermore, an unreasonable landowner may use delaying tactics under existing procedures to force the local planning agency into an exorbitant out of court settlement. ${ }^{10}$

\footnotetext{
-For discussion of the various land disposition techniques in use, see Scheuer, Goldston \& Sogg, Disposition of Urban Renewal Land-A Fundamental Problem in the Rebuilding of Our Cities, 62 Colum. L. Rev. 959 (1962); Comment, 68 YaLe L.J. 1424 (1959).

- Two independent appraisals of each tract in the project area are required before the local planning agency can acquire any land for the project. If the discrepancy between them is too great, a third appraisal must be conducted. See URWAN RENEwAL Manual § 13-2-1.

" "Local public agency" or "agency" in this comment will mean the entity or public body authorized to undertake renewal programs. See 68 Stat. 629 (1954), 42 U.S.C. § $1460(\mathrm{~h})$ (1958). Governing bodies, housing agencies, redevelopment and planning commissions, or a combination of these, have been designated as the local planning agency by the various state enabling acts. See Johnstone, supra note 2, at 316.

${ }^{8}$ See Pet Car Prods., Inc. v. Barnett, 150 Conn. 42, 184 A.2d 797 (1962) (petition to condemn not filed until $\mathbf{3 3}$ months after project approval).

- Several cases have mentioned that the property involved in the case is needed for a redevelopment contract. See Bahr Corp. v. O'Brion, 146 Conn. 237, 149 A.2d 691 (1959); In re Baden-Ormond, 35 Misc. 2d 974, 231 N.Y.S.2d 679 (Sup. Ct. 1962); Grisanti v. City of Cleveland, I8 Ohio Op.2d I43, 179 N.E.2d 798 (C.P. 1961), af'd, 181 N.E.2d 299 (Ohio Ct. App.), appeal dismissed per curiam, 173 Ohio St. 386, 182 N.E.2d 568, appeal dismissed per curiam, 371 U.S. 68 (1962). In the former case, the agency had to default but it was able to renegotiate the contract. See Note, 69 YALE L.J. 321, 327, 328 n.44 (1959).

10 There is some evidence that such a "hold-up" has been successful. See Note, 69 YALE L.J. 321, 324 n.24 (1959). In a few cases, the local planning agency has tried without success to prove a claim of laches against a condemnee. See Bahr Corp. v. O'Brion, 146 Conn. 237, 243-44, 149 A.2d 691, 695-96 (1959); Grisanti v. City of Cleveland, 179 N.E.2d 798, 804-05 (Ohio C.P. 1961).
} 


\section{The "Public Use" Requirement}

The power to take private property by eminent domain is viewed as as inherent political right of a sovereign, limited only by constitutional and statutory provisions. ${ }^{11}$ Provided that the requirement of just compensation has been discharged, ${ }^{12}$ the taking of property for a public use, in compliance with the statutes authorizing eminent domain, satisfies the due process requirement of the fourteenth amendment. ${ }^{13}$ According to established principles, questions relating to the necessity or expediency of the taking are considered discretionary questions for legislative resolution. Such non-judicial issues include the decision to use eminent domain, the extent of the estate taken, the need for a particular tract, and the amount of land which will be affected. ${ }^{14}$

Traditionally, public use was literally construed to require use of the acquired property by the public. ${ }^{15}$ More prevalent today, however, is the view that eminent domain may be exercised as a means of achieving any legitimate governmental objective substantially related to the public welfare. ${ }^{16}$ The overwhelming number of cases upholding the constitutionality of urban renewal enabling stattutes have done so on the basis that alleviation of slum and blight conditions is for the public welfare. ${ }^{17}$

\footnotetext{
${ }^{11}$ See, e.g., Hays v. Port of Seattle, 251 U.S. 233 (1920); Redevelopment Comm'n v. Hagins, 258 N.C. 220, 223, 128 S.E.2d 391, 395 (1962); I Nichors, EMINENT DoMAIN $\S 4.3$ '(3d ed. Sackman \& Van Brunt 1950) [hereinafter cited as NichoLs].

12 The due process clause of the fourteenth amendment has been construed to require the payment of just compensation for the taking of private property by the states. Chicago B. \& Q. R.R. v. Chicago, 166 U.S. 226 (1897); 1 Nichous $§ 4.8$. The determination of the amount of compensation is a separate issue in each case and does not by itself endanger acquisition of the property by the agency. For a discussion of the difficult valuation problems involved in using eminent domain for urban renewal projects, particularly with respect to consequential damages, see Berger, Current Problems Affecting Costs of Condemnation, 26 Law \& ConTeMr. ProB. 85 (1961); Kratovil \& Harrison, Eminent Domain-Policy and Concept, 42 CAIrF. L. Rev. 596 (1954); Comment, 67 YALE L.J. 61 (1957).

${ }^{13}$ U.S. ConsT. amend. XIV, $\$ 1$. See generally I Nichols $\$ \S 4.3-.10 ; 2$ Id. $\$ \S 7.1-.5$.

${ }^{14}$ See 1 Nichors \$ 4.11; Lavine, Extent of Judicial Inquiry Into Power of Eminent Domain, 28 So. CAL. L. REv. 369 (1955).

${ }^{15}$ See cases cited in 2 Nichors $\$ 7.2(1)$ n.23.

${ }^{10}$ E.g., Berman v. Parker, 348 U.S. 26 (1954); Gity Housing Authority v. Muller, 270 N.Y. 333, I N.E.2d 153 (1936). See generally Dunham, Griggs v. Allegheny County In Perspective-Thirty Years of Supreme Court Expropriation Law, 1962 SUP. Cr. REv. 63, 66-71; Marquis, Constitutional and Statutory Authority To Condemn, 43 IowA L. REv. 170, 172-82 (1958); Nichols, The Meaning of Publie Use in the Law of Eminent Domain, 20 B.U.L. REv. 615 (1940).

${ }^{17}$ E.g., Redevelopment Agency v. Hayes, 122 Cal. App. 2d 777, 266 P.2d 105, cert. denied, 348 U.S. 897 (1954); Miller v. City of Tacoma, 378 P.2d 464 (Wash. 1963).
} 
Once an enabling statute has been held constitutional, the question of the public purpose of a project carried out under the statute is conclusively established.18 Seemingly, therefore, the only remaining justiciable issues cognizable in an eminent domain proceeding involving project property relate to compliance with the provisions of the eminent domain and enabling acts. ${ }^{10}$ This is the view of the United States Supreme Court. In the 1954 case of Berman v. Park$e r,{ }^{20}$ the Court narrowly limited the scope of judicial review of urban renewal projects:

Once the question of public purpose has been decided, the amount and character of land to be taken for the project and the need for a particular tract to complete the integrated plan rests in the discretion of the legislative branch.... The rights of ... [the] property owners are satisfied when they receive $\ldots$ just compensation. ${ }^{21}$

\section{The Necessity of Statutory Compliance}

The cases dealing with redevelopment projects clearly indicate that proof of compliance with the procedures outlined in the enabling act is a jurisdictional prerequisite for instituting an eminent domain proceeding. In Redevelopment Comm'n v. Hagins, ${ }^{22}$ the North Carolina Supreme Court dismissed a petition to condemn for

Only three states have held enabling acts unconstitutional. See Adams v. Housing Authority, 60 So.2d 663 (Fla. 1952); Housing Authority v. Johnson, 209 Ga. 560, 74 S.E.2d 891 (1953); Edens v. City of Columbia, 228 S.C. 563, 91 S.E.2d 280 (1956). Subsequent cases in Florida and Georgia, however, have upheld redevelopment legislation. Grubstein v. Urban Renewal Agency, 115 So.2d 745 (Fla. 1959) (limited to slum clearance); Bailey v. Housing Authority, 214 Ga. 790, 107 S.E.2d 812 (1959) (constitutioual and statutory amendments). For discussions of the variety of constitutional objections to these enabling acts, see Annot., 44 A.L.R.2d 1414 (1955); Osgood \& Zwerner, Rchabilitation and Conservation, 25 LAw \& CoNTEMP. Prop. 705, 711-17 (1960); Comment, 58 YALE L.J. 599 (1949). Some state courts have expressed reservations on enabling legislation authorizing certain types of programs, such as reclamation of open blighited areas, but no case has held the enabling language unconstitutional. Compare Miller v. City of Tacoma, supra at 471-72, with Cannata v. City of New York, 11 N.Y.2d 210, 182 N.E.2d 395, 227 N.Y.S.2d 903 (1962).

${ }^{18}$ See, e.g., Redevelopment Comm'n v. Hagins, 258 N.C. 220, 223, 128 S.E.2d 391, 393 (1962).

${ }_{19}$ While the requirements for a petition to condemn vary greatly from state to state, in general only three types of jurisdictional facts are considered esscntial: the petitioner's name and position; facts showing completion of all the preliminary procedural requirements; and facts declaring the purpose of the taking, including a description of the property and the interest to be taken. Many states in addition require proof that the condemning agency has made a good faith effort to purchase the property. Sce Wasserman, Procedure in Eminent Domain, 11 MERCER L. REv. 245, 268.69 (1960).

20348 U.S. 26 (1954).

22 Id. at $35-36$.

22258 N.C. 220 , 128 S.E.2d 391 (1962). 
failure of the local planning agency to show that, pursuant to statute, there was a properly approved redevelopment plan. ${ }^{23}$ Similarly, in Sheeneen $v$. Altschuler, ${ }^{24}$ the Supreme Court of Errors of Connecticut held unlawful all acquisitions of property in a project area because of two substantial irregularities: the members of the redevelopment agency had not received the requisite approval of the governing board of the city, and the agency had initiated acquisition procedures before holding the required public hearing.

While courts will demand proof that the prescribed statutory procedures have been formally observed before authorizing a project taking by eminent domain, they are unwilling to inquire into the substance of these required proceedings. For example, if the required number of public hearings has been held, a court will not entertain a condemnee's challenge to the validity of the plan on the ground that not everyone present was allowed to speak or that the meeting was rowdy. ${ }^{25}$ Moreover, proof of de facto compliance with the notice requirements for public hearings is sufficient. ${ }^{26}$ The justification for these holdings is twofold. In the first place, a public hearing is not constitutionally required during the planning stage of a redevelopment project, since only legislative questions concerning the scope and boundaries of the plan are determined. ${ }^{27}$ Secondly, there is an understandable judicial reluctance to overturn an otherwise valid and carefully planned project on what amount to inconșequential technicalities, since the affected property owners are entitled to notice and a hearing in a condemnation proceeding on the judicially cognizable issues that could have been raised in the public hearings. ${ }^{28}$

\footnotetext{
${ }^{23}$ Id. at 225, 128 S.E.2d at 393. N.C. GEN. STAT. \$ 160-463 (d) (Supp. 1961) requires a properly approved redevelopment plan showing: the boundaries of the area, existing and proposed land uses, population density, proposed changes in zoning ordinances, street layouts, a feasible relocation plan for displaced persons, and a statement of estimated costs and method of financing the project.

24 148 Conn. 517, 172 A.2d 897 (1961).

${ }^{25}$ See, e.g., Wilson v. City of Long Branch, 27 N.J. 360, 383-90, 142 A.2d 837, 850-54, cert. denied, 358 U.S. 873 (1958); Beebe Improvement Corp. v. City of New York, 129 N.Y.S.2d 263, 266 (Sup. Ct. 1954). A minimum of one hearing before project approval and compliance with local provisions for other hearings is a prerequisite for HHFA approval of the Loan and Grant Contract. See Urban Renewal ManUal \$ 4-3.

${ }^{20} \mathrm{See}$ Griggs v. Borough of Princeton, 33 N.J. 207, 224-25, 162 A.2d 862, 872 (1960);

Stahl v. Board of Fin., 62 N.J. Super. 562, 588, 163 A.2d 396, 411 (L. 1960).

${ }^{27}$ See Rindge Co. v. County of Los Angeles, 262 U.S. 700 (1923); Robinette v. Chicago Land Clearance Comm'n, 115 F. Supp. 669 (N.D. I1l. 195̃1); Zurn v. City of Chicago, 389 Ill. 114, 59 N.E.2d 18 (1945).

as United States v. Carmack, 329 U.S. 230, $242-43$ (1946); Ross v. Chicago Land
} 
However, one major problem involving the necessity of statutory compliance remains unsettled. Most states have provisions in their urban renewal and eminent domain statutes prohibiting a member of a local planning agency or governing body from acting on any matter in which he has a personal or financial interest. ${ }^{20}$ The cases to date indicate that, under such a provision, the resolutions of the agency and city council approving the redevelopment plans are voidable if a member with a disqualifying conflict of interest votes to approve the plan..$^{30}$

The cases do not clearly indicate, however, what constitutes a disqualifying interest under these conflict-of-interest statutes. ${ }^{31} \mathrm{~A}$ member of a local planning agency or city council owning an interest in property within the project area would be within the statutory prohibition. ${ }^{32}$ When the potential pecuniary or personal benefit is remote, however, the officer's vote apparently does not invalidate the approving resolutions. Thus, no disqualifying conflict of interest arises where a member of the agency or city council is an officer and stockholder of a bank which holds mortgages on some property in a project area. ${ }^{33}$ Between these extremes, the test seems to be whether

Clearance Comm'n; 413 Ill. 377, 108 N.E.2d 776 (1952); 1 Nichols $\$ 4.103$; Comment, 4 ST. Louis U.L.J. 339 (1957).

29 E.g., Cal. Health \& Safety Code $\$ 33236$; N.J. Stat. ANN. \$ 40:55-1.4 (Supp. 1962); N.Y. VILLAGE. LAw $\$ 332$. The coverage and penalties of these statutes vary widely, but the effect on the resolutions and contracts involved is the samc. Sce 2 McQuillin, Municipal Corporations $\$ 531$ (2d ed. DeFuniak 1939) [hereinafter cited as McQuILLIN]; Note, 12 Rutgers L. REv. 582' (1958).

${ }^{80}$ Griggs v. Borough of Princeton, 33 N.J. 207, 216-22, 162 A.2d 862, 867-70 (1960); Baker v. Marley, 8 N.Y.2d 365, 170 N.E.2d 900, 208 N.X.S.2d 449 (1960). This is apparently consonant with the common law rule. See 2 McQuiLlin $\$ \S 531,629 ; 3$ id. $\$ 1354$. Redevelopment contracts and rezoning ordinances made in conjunction with urban renewal projects would also be voidable under these statutes if a conflict of interest were present. See Bracey v. City of Long Branch, 73 N.J. Super، 91,179 A.2d 63 (L. 1962).

81 See generally 3 McQuiLLiN \$ 1354; Kaplan \& Lillich, Municipal Gonflicts of Interest: Inconsistencies and Patchwork Prohibitions, 58 CoLUM. L. REv. 157, 171-81 (1958); Kennedy \& Beck, Interest of Public Officers in Contracts Prohibited by Law, 28 So. Cal. L. REv. 335, 339-47 (1955).

${ }^{82}$ Baker v. Marley, 8 N.Y. 2d 365, 170 N.E.2d 900, 208 N.Y.S.2d 449 (1960). Sce Spadanuta v. Incorporated Village of Rockville Centre, 16 App. Div. 2d 966, 230 N.Y.S.2d 69 (1962), aff'd, 12 N.Y.2d 895, 188 N.E.2d 266, 237 N.Y.S.2d 1002 (1963) (mayor owned property in project area at time preliminary plans were drawn up); Benincasa v. Incorporated Village of Rockvilie Centre, 33 Misc. 2d 13, 215 N.Y.S.2d 575 (Sup. Ct. 1961) (mayor's property contiguous to project area). In both these cases, injunctions were denied on the basis that the statute applied only if the property owned by the member of the city council wore included in the final project plan.

${ }^{38}$ Wilson v. City of Long Branch, 27 N.J. 360, 395-96, 142 A.2d 837, 857, cert. denied, 
the circumstances would have "the likely capacity to tempt the officer to depart from his ... public duty." 34 The considerable discretion given to public officers in planning urban renewal programs and the vast amounts of land, money and people involved in such project. will undoubtedly influence courts to strictly construe these statutes. To avoid the possibility of an injunction restraining acquisition of project land by eminent domain and voiding all prior acquisitions, it is suggested that a member of a local planning agency or city council fully disclose any possible interest he might have in a project and refrain from voting on any aspect of the project plans. ${ }^{35} \quad::$

\section{Judicial Review of Planning Determinations}

Federal decisions since Berman v. Parker ${ }^{36}$ have summarily dismissed all attacks on determinations made in the planning stage of District of Columbia projects and have perfunctorily granted decrees for eminent domain. ${ }^{37}$ State decisions involving eminent domain proceedings, on the other hand, have shown a greater proclivity to review the planning decisions to determine whether they were made so arbitrarily and capriciously as to constitute an abuse of discretion. ${ }^{38}$

358 U.S. 873 (1958); accord, Bracey v. City of Long Branch, 179 A.2d 63, 67 (N.J. Super. Ct. L. 1962). (1958).

34 Van Itallie v. Borough of Franklin Lakes, 28 N.J. 258, 268, 146 A.2d 111, 116

${ }^{35}$ Apparently disclosure and abstention from voting is a sufficient defense to such charges. See Griggs v. Borough of Princeton, 33 N.J. 207, 217, 162 A.2d 862, 867-68 (1960); Aldom v. Borough of Roseland, 42 N.J. Super. 495, 127 A.2d 190 (App. Div. 1956). But see J. J. Carroll, Inc. v. Waldbauer, 219 N.Y.S.2d 436 (Sup. Ct. 1961). If the determination of blight or approving resolutions of a local planning agency or city council were declared voidable on conflict of interest grounds, the offending members might have to resign before valid resolutions could be passed. See $\mathrm{S} \& \mathrm{~L}$ Associates, Inc. v. Township of Washington, 35 N.J. 224, 172 A.2d 657 (1961); Griggs v. Borough of Princeton, supra at 220-21, 162 A.2d at 869-70 (1960). See cases cited in 3 McQurLLIN $\S 1359$ n.78. At the very least, the effect in such cases would be to unnecessarily delay the implementation of a project.

In states which have no statutory provisions relating to conflict of interest, however, it is doubtful that a court would enjoin a taking on this basis in the absence of clear proof of fraud or actual bad faith. The established rule is that the motives of officials who take part in approving a public improvement project are not reviewable in an eminent domain proceeding. See Deerfield Park Dist. v. Progress Dev. Corp., 186 N.E.2d 360, 361 (IIl. 1962); Bowker v. City of Worcester, 334 Mass. 422, 432, 136 N.E.2d 208, 213 (1956); 6 NICHOLS $\$ 26.1314$.

${ }^{38} 348$ U.S. 26 (1954).

${ }^{37}$ Mamer v. District of Columbia Redevelopment Land Agency, 284 F.2d 221 (D.C. Gir. 1960); Donnelly v. District of Columbia Redevelopment Land Agency, 269 F.2d 546 (D.C. Cir. 1959), cert. denied, 361 U.S. 949 (1960).

${ }^{88}$ E.g., Graham v. Houlihan, 147 Conn. 321, 160 A.2d 745, cert. denied, 364 U.S. 
State courts, however, are unwilling to review most of the major planning decisions in suits growing out of condemnation proceedings. Thus, it is clear that the decision to redevelop an area as residential, commercial, or industrial is exclusively within the discretion of the local planning agency. ${ }^{39}$ Moreover, the determination of the boundaries of a project area is not open to judicial review. ${ }^{40}$ Furthermore, the decision to exclude non-blighted property from the project area is clearly within the agency's discretion. ${ }^{41}$

There is a conflict in the state decisions, however, concerning the aggrieved landowner's right to challenge the inclusion of his particular non-blighted property in a project. Many courts ${ }^{42}$ have summarily rejected such a contention, concluding that the decision of what property should be included in the plan lies exclusively within the discretion of the agency. Nevertheless, there seems to be a discernible tendency for courts to hold a hearing de novo on the issue of inclusion, particularly when commercial and industrial property is at stake. ${ }^{43}$ In Pet Car Prods., Inc. v. Barnett, ${ }^{44}$ the Supreme Court of Errors of Connecticut pointed out that:

If the plaintiff's buildings were permitted to remain, an L-shaped parcel difficult to dispose of because of its configuration would exist, the required setbacks would leave a very narrow strip of land on one street on which it would be difficult to erect a sizable building, and there would be an inefficient utilization of land and unsatisfactory provision for truckturning areas. The plaintiff's property was so located as to be of key importance to the suitable development of the remainder of the ... area and the structures on it would tend to establish the character of the area for other industrial users.45

\footnotetext{
883 (1960); Urban Renewal Agency v. Iacometti, 379 P.2d 466, 468 (Nev. 1963); Grisanti v. City of Cleveland, 181 N.E.2d 299, 302-05 (Ohio Ct. App. 1962), affirming, 18 Ohio Op.2d 148, 179 N.E.2d 798 (C.P. 1961).

${ }^{39}$ Worchester Knitting Realty Co. v. Worchester Housing Authority, 335 Mass. 19, 138 N.E.2d 356 (1956).

${ }^{10} I d$. at 22,138 N.E.2d at 358.

${ }^{11}$ E.g., Berman v. Parker, 348 U.S. 26, 34-35 (1954); Boro Hall Corp. v. Iinpelliterri, 128 N.Y.S.2d 804 (Sup. Ct.), aff'd, 283 App. Div. 889, 130 N.Y.S.2d 6 (1954); Grisanti v. City of Cleveland, 18 Ohio Op.2d 143, 179 N.E.2d 798 (C.P. 1961), aff'd, 181 N.E.2d 299 (Ohio Ct. App.), appeal dismissed per curiam, 173 Ohio St. 386, 182 N.E.2d 568, appeal dismissed per curiam, 371 U.S. 68 (1962).

12 See cases cited note 41 supra.

13 Pet Car Prods. Inc. v. Barnett, 150 Conn. 42, 184 A.2d 797 (1962); Bahr Corp. v. O'Brion, 146 Conn. 237, 248-49, 149 A.2d 691, 696.97 (1959); Housing \& Redevelopment Authority v. Minneapolis Metropolitan Co., 104 N.W.2d 864, 875 (Minn. 1960); Carroll v. City of Camden, 34 N.J. 575, 170 A.2d 417 (1961).

14150 Conn. 42, 184 A.2d 797 (1962).

45 A.2d at $800-01$
} 
These decisions indicate that a reviewing court will be satisfied with the validity of the taking if there is some reasonable planning justification, as there was in Pet Car Products, to include a particular nonblighted property. ${ }^{46}$ In a well-planned project, such planning data will have been considered by the agency before drawing up the final plans. ${ }^{47}$ Thus, in most cases, the only effect of a court hearing on this determination in an eminent domain proceeding will be to force the agency to disclose these planning considerations. ${ }^{48}$

No case has yet invalidated a taking on the basis that the determination to include it in the plan was arbitrary and capricious. Many considerations, however, might persuade a court to make such a decision. Most urban renewal enabling acts contain a limitation to the effect that the local planning agency can only acquire property which is "necessary or incidental" 40 for the completion of an adequate unit of development. This statutory limitation could be invoked if no planning justification for the land in question is found. Similarly, it would seem that there could be no legal basis to condemn a non-blighted building that could be rehabilitated and suc cessfully integrated into a project plan..$^{50}$ Moreover, it is clearly within the agency's discretion to exclude non-blighted property from a project area; but this leaves open the question of the basis upon which the decision was made to include some non-blighted tracts while excluding others. In Grisanti $v$. City of Cleveland, ${ }^{51}$ one hundred and thirty-one out of four hundred and twenty-nine businesses were excluded from the project plan. The danger of special

\footnotetext{
"See cases cited note 43 supra.

17 It is specifically required that an explanation of why a particular non-blighted property is included in the plan shall be submitted to the HHFA in the application for the Loan and Grant Contract. URBan Renewal Manual § 10-4-2 (6) (c).

${ }^{8}$ See Sullivan, Administrative Procedure and the Advocatory Process in Urban Redevelopment, 45 CALIF. L. REV. 134, 146-47 (1957).

'Dee N.C. Gen. Stat. \$ 160-456(r) (Supp. 1961); Conn. Gen. Stat. AnN. \$ 8-125 (b) (1960) (area may include structures which are found to be "essential" to complete an adequate unit of development). Furthermore, according to established common law principles, a taking of property without any showing of necessity or need would be illegal. See Deerfield Park Dist. v. Progress Dev. Corp., 26 Ill. 2d 296, 186 N.E.2d 360 (1962); Winger v. Aires, 371 Pa. 242, 89 A.2d 521 (1952) (abuse of discretion to condemn 55 acre tract for school housing 65 pupils); 1 Nichoss $\$ 4.11$ (3).

${ }^{\circ 0}$ See Pet Car Prods., Inc. v. Barnett, 184 A.2d 797, 802 (Conn. 1962); Housing \& Redevelopment Authority v. Minneapolis Metropolitan Co., 104 N.W.2d 864, 874-75 (Minn. 1960); Note, 68 HARv. L. REv. 1422, 1429-32 (1955).

"2 18 Ohio Op. 2d 143, 179 N.E.2d 798 (C.P. 1961), aff'd, 181 N.E.2d 299 (Ohio App. Div.), appeal dismissed per curiam, 173 Ohio St. 386, 182 N.E.2d 568, appeal dismissed per curiam, 371 U.S. 68 (1962).
} 
favors and arbitrary discrimination in such a situation seems suffcient to require some showing of the need to take an aggrieved landowner's non-blighted property. Finally, a holding invalidating a particular taking would not invalidate the whole redevelopment project, although it might necessitate some changes in the original plan. ${ }^{52}$

The state courts are also divided on the appropriateness of reviewing, in an eminent domain proceeding, the planning determination that the project area in fact qualifies as a slum or blighted area within the terms of the enabling act. A majority of courts will not allow a complaining landowner to controvert the finding of blight with extrinsic evidence if there is substantial evidence in the planning stage records to support the agency determination. ${ }^{63}$ The reasoning most often advanced is that a court has no power to substitute its opinion for that of the official agencies. which have conducted expert investigations and public hearings. ${ }^{54}$ These courts indicate, however, that a triable issue will exist where the condemnee alleges sufficient facts to make the determination of blight baseless and irrational as a matter of law. .5

A few courts, however, have held that an agency's determination that blight exists is judicially reviewable. ${ }^{50}$ These courts will hold a

\footnotetext{
"In most instances, the contesting landowner has challenged the validity of the project as a whole rather than limiting his attack to the inclusion of his particular non-blighted property. See, e.g., Grisanti v. City of Cleveland, supra note 51. Some decisions indicate, however, that the scope of judicial review would be bronder if only the inclusion of particular tracts is contested. See Urban Renewal Agency v. Iacometti, 379 P.2d 466, 470 (Nev. 1963).

${ }^{53}$ E.g., Urban Renewal Agency v. Iacometti, 379 P.2d 466, 468-69 (Nev. 1963); Wilson v. City of Long Branch, 27 N.J. 360, 142 A.2d 837, cert. denied, 358 U.S. 873 (1958); Kaskel v. Impelliterri, 306 N.Y. 73, 115 N.E.2d 659 (1953), cert. denied, 347 U.S. 934 (1954). See also Graham v. Houlihan, 147 Conn. 321, 329, I60 A.2d 745, 75I, cert. denied, 364 U.S. 833 (1960) (agency need not personally examine planning statistics before declaring area blighted if decision itself is sound); Spadantita $v$. Incorporated Village of Rockville Centre, 230 N.Y.S.2d 69, 71 (App. Div. 1962), aff'd, 12 N.Y.2d 895, 188 N.E.2d 266, 237 N.Y.S.2d 1002 (1963) (project not invalid even if certain buildings "fraudulently" declared substandard, so long as area itself qualifies). But see Bristol Redevelopment \& Housing Authority v. Denton, 198 Va. 171, 93 S.E.2d 288 (1956).

6s See the leading case of Kaskel v. Impelliterri, 306 N.Y. 73, I15 N.E.2d 659 (1953), cert. denied, 347 U.S. 934 (1954).

${ }^{55} I d$. at 80,115 N.E.2d at 663 . In Beebe Improvement Corp. v. City of New York, 129 N.Y.S.2d 263 (Sup. Ct. 1954) the court on authority of the Kaskel case, remanded for a hearing de novo on the question of whether the area qualified under the statutory definition. The city then abandoned its attempt to condemn the land. Sec Diehm V. City of New York, 208 Misc. 209, 143 N.Y.S.2d 298 (Sup. Ct. 1955).

${ }^{\text {so }}$ See Offen v. City of Topeka, 186 Kan. 389, 350 P.2d 33 (1960); Bristol Redevelop.
} 
hearing de novo on this issue merely upon the allegation of an arbitrary and capricious decision. There seems to be little justification for this minority view, and the only effect of a hearing on the issue of blight is to needlessly protract condemnation proceedings involving project property. The determination of blight must be made in accordance with approved Housing and Home Finance Ágency standards before the necessary federal funds to implement the project will be authorized. ${ }^{5 \pi}$ Furthermore, the majority rule is sufficiently rigorous to deal with the few cases where the determination of blight is clearly erroneous. 58

A few decisions indicate that at least some courts will carefully scrutinize the financial and relocation aspects of a project plan in suits growing out of eminent domain proceedings.59 These courts will not entertain contentions that the local planning agency must provide for the relocation of every family displaced by a project, or have on hand cash to pay for all the property prior to commencing with property acquisition. Nevertheless, before validating, a taking of project property, these decisions have required proof of compliance with the state and strict federal relocation and financial requirements. ${ }^{60}$

ment \& Housing Authority v. Denton, 198 Va. 171, 93 S.E.2d 288 (1956). But see Davis v. City of Lubbock, 160 Tex. 38, 326 S.W.2d 699 (1959) (statute allowing courts to hold de novo hearing on issue of blight declared unconstitutional).

${ }^{67}$ See Urban Renewal Manual \$\$ 3-1, 3-2, 10-1, 10-4-1, 10-4-2; Johnstone, The Federal Urban Renewal Program, 25 U. CHI. L. Rev. 301, 303-05 (1958).

${ }^{\text {os }}$ See note 55 supra. In only one case has the determination of blight been overturned. Bristol Redevelopment \& Housing Authority v. Denton, 198 Va. 171, 93 S.E.2d 288 (1956). Accord, Hogue v. Port of Seattle, 54 Wash. 2d 799, 341 P.2d 171 (1959) (determination of marginal land set aside under industrial development act). One court has gone to the opposite extreme and held that the designation of the area as a slum is conclusive on the court. Allen v. City Council, 215 Ga. 778, 113 S.E.2d 621 (1960). This case has been severely criticized by the commentators. See Weinstein, Judicial Review in Urban Renewal, 21 FED. B.J. 318, 329 (1961); 74 HARv. L. REv. 799 (1961).

${ }^{50}$ See Housing \& Redevelopment Authority v. Minneapolis Metropolitan Co., 104 N.W.2d 864, 873 (Minn. 1960); Redevelopment Comm'n v. Hagins, 258 N.C. 220, 224, 128 S.E.2d 391, 394 (1962). Contra, Spadanuta v. Incorporated Village of Rockville Centre, 33 Misc. 2d 499, 501, 224 N.Y.S.2d 963, 965-66 (Sup. Ct. 1962); Hunter v. City of New York, 121 N.Y.S.2d 841 (Sup. Ct. 1953).

${ }^{00}$ See cases cited note 59 supra; cf. Horton v. Redevelopment Comm'n, 259 N.C. 605, 131 S.E.2d 464 (1963) (approval of city voters required before ad valorem tax money can be used for project). The relocation plans required by the HHFA before it will sigu the Loan and Grant Contract are set forth in URBAN RENEWAL MANUAL $\$ \S$ $16-1,16-2-2$; the HHFA financial requirements are set forth in $I d$. at $\$ \$ 30-1-1,31-1-1$ to $-2-4,60-1-1$ to $-4-3$. 


\section{Eminent Domain Procedure}

While a court may invalidate a particular taking, the time-consuming delays inherent in the antiquated eminent domain procedures which exist in most states today are potentially the most, dangerous stumbling block to an efficient land acquisition program. $^{61}$

According to well established principles, a landowner has the right to challenge the legality of the taking of his property at any time prior to a final judgment on the issue of compensation. ${ }^{62}$ The legality of a particular taking and the status of a project as a whole remain in doubt during this entire period. Furthermore, title to the condemned land does not pass to the local planning agency in most states until final determination and payment of the compensation award, thus hindering the agency's efforts to sell or lease project property. ${ }^{63}$

Most states now have statutory devices designed to make eminent domain proceedings less cumbersome and time-consuming. Several have statutes giving condemnation proceedings priority in the courts. $^{64}$ And a majority of states now have provisions allowing joinder of several condemnation suits. ${ }^{6 s}$ Even in states where joinder is not authorized by statute, a state court may, barring a specific statutory prohibition, join all the pending suits for a preliminary hearing on the validity of the taking, so long as there is a separate trial for each landowner on the issue of compensation. ${ }^{66}$

${ }^{61}$ See generally Stevens, Confusion in Condemnation Procedure, 6 Kan. Jud. Councic Bulr. 18 (1932); Wasserman, Procedure in Eminent Domain, 11 Mercer L. REv. 245 (1960); Comment, 29 FordhaM L. REv. 757 (1961).

${ }^{62}$ Depending on local law, a hearing on all issues other than compensation can be held in a plenary injunctive action, Grisanti v. City of Cleveland, 179 N.E.2d 798, 804-05 (Ohio C.P. 1961); or before the condemning court, Redevelopment Comm'n v. Hagins, 258 N.C. 220, 128 S.E.2d 391 (1962); 6 Nicroos $\$ 26.3$. In the latter situation, the judgment in favor of the condemnor in the preliminary hearing is generally considered interlocutory and non-appealable until after the initial award of compensation. See cases cited 6 Nichors $\$ 26.32$.

${ }^{63}$ See, e.g., Topping v. North Carolina State Bd. of Educ., 249 N.Ci 291, 106 S.E.2d 502 (1959). The delay from the filing of the petition to condemn to the date of vesting of title may be as long as fifteen months. See Comment, 41 ILL. L. REv. 82, 83-84 (1946).

es Cal. Crv. Proc. \$ 1264; TenN. Code ANN. \$ 54-919 (1955); Wis. Stat. \$ $32.06(5)$ (1961).

${ }^{65}$ E.g., Cal. Grv. Proc. $\$ 1244$ (5); Icr. Rev. Stat. ch. 47, 55 (Smith-Hurd Supp. 1962). Damages for each parcel must be separately assessed. See 6 NichoLs $\S 26.1132$. If multiplicity of suits in such a procedure results in confusion, due process may be violated. See Gwathmey v. United States, 215 F.2d 148, 157 (5th Cir. 1954).

${ }^{6 B}$ Such a procedure was recently authorized by the North Carolina Supreme Court 
Thus, the local planning agency can acquire all the property needed for a project in one or more blanket eminent domain proceedings. Further, most states now have statutes which permit the condemning authority to take temporary possession of the property, pending final determination of all the justiciable issues. ${ }^{67}$ While this procedure allows the local planning body to prepare the land for redevelopment, the agency is nonetheless precluded from selling or leasing the property until full title has been acquired by payment of the final compensation award. ${ }^{68}$

It is submitted that two statutory reforms may help further reduce the deficiencies that now exist in the use of eminent domain for land acquisition in urban renewal projects. The first is a statute giving a property owner in a project area the right of appeal to a court within a reasonable time after approval of the project plan. All justiciable issues, including the determination that the project area is blighted, abuse of discretion, statutory irregularities, and possible conflicts of interest could be raised in such a suit. The determination of these issues would be conclusive against all affected property owners, ${ }^{69}$ leaving only the question of compensation and minor questions, such as whether the land being taken is within the boundaries of the project area, to be decided in a later eminent domain proceeding.

Such legislation, already enacted in several states, ${ }^{70}$ results in an

in Redevelopment Comm'n v. Hagins, 258 N.C. 220, 225-26, 128 S.E.2d 391, 394-95 (1962). See 6 Nichols $\$ 26.1134$.

${ }^{\circ 7}$ In general, the agency is required to deposit the initial determination of compensation with the court before an order granting temporary possession is granted. See, N.Y. Condex. Law \$ 24; N.C. GeN. STat. \$ 40-19 (1950); Berger, Current Problems Affecting Costs of Condemnation, 26 LAw \& ConTeMp. Prob. 85, 100-03 (1961); Dodge, Land Acquisition for State Highways, 1953 WIs. L. REv. 458, 462; Wasserman, supra note 61 , at 274-78. Other statutes not only allow early possession, but also permit early vesting of title in the condemning authority.

${ }^{\circ}$ See note 63 supra. Moreover, the condemnee loses the right to challenge any issue other than the determination of compensation in a later stage of the proceeding in many states if he draws down any of the compensation deposited with the court. See State v. Howald, 315 S.W.2d 786 (Mo. 1958). The theory seems to be that withdrawal of the money is inconsistent with protesting the validity of the taking. See 6 Nichols $\$ 28.321(2)$.

${ }^{\circ}$ Where the statutory right to appeal from an administrative decision exists, the findings of the agency cannot be challenged in a subsequent condemnation proceeding even if no appeal is taken. See Peoples Gas Light \& Coke Co. v. Buckles, 182 N.E.2d 169, 174 (III.), cert. denied, 371 U.S. I85 (1962).

${ }^{70}$ See Cal. Health \& SAfETy CODE $\$ 33746$ (60 day right of appeal to courts after adoption of project plan); Mass. Stat. 1960, ch.652, $\$ 13$; N.J. STAT. ANN. $\$ 40: 55-21.9$ (Supp. 1961) (30 day right to appeal determination of blight). Review by a court of the planning determinations follows that established for other administrative agencies 
early resolution of all the principal issues concerning the legality of a plan. The local planning agency can then proceed with land acquisition without the fear of a decision declaring the whole project illegal months and possibly years after its approval. Moreover, such a statute gives the aggrieved landowner an effective means of challenging the validity of a project and adequately protects his constitutional rights. The well-established limitations on the scope of judicial review, and the time-consuming nature of eminent domain proceedings, make such actions inappropriate for deciding the great number of potentially justiciable issues that arise out of redevelopment projects. Yet an individual landowner has, in most states, no other effective means of challenging the legality of planning decisions in advance of an eminent domain proceeding. ${ }^{71}$ And in several states an aggrieved landowner is precluded from challenging any aspect of a plan except in a condemnation proceeding. ${ }^{\mathbf{7 2}}$

Secondly, the adoption of what are known as "quick-taking" statutes, ${ }^{73}$ which vest title to project property in the local planning

in Illinois for a project under the Neighborhood Redevelopment Act. ILL. ANN. STAT. ch. $671 / 2, \S 280-1$ (Smith-Hurd Supp. 1962); but there is no statutory or common law right to judicial review before a condemnation suit if the project is under the Illinois Blighted Areas Redevelopment Act. Shapiro v. Chicago Land Clearance Comm'n, 19 Ill. App. 2d 461, I54 N.E.2d 329 (1958).

${ }^{71}$ In some states, a landowner may have the right to challenge certain aspects of the plan by a prerogative writ, injunctive or declaratory judgment action, but the basis or scope of such a right seems unclear. See Sogg \& Wertheimer, Urban Renewal: Problems of Eliminating and Preventing Urban Deterioration, 72 HARv. L. REv, 504, 515-19 (1959). Suits in state and federal courts to enjoin HHFA officials from carrying out various aspects of the plan have had a uniform lack of success. Sec, e.g., HarrisonHalstead Community Group, Inc. v. HFFA, 310 F.2d 99 (7th Cir. 1962), cert. denied, 373 U.S. 914 (1963); Spadanuta v. Incorporated Village of Rockville Centre, 33 Misc. 2d 499, 50I, 224 N.Y.S.2d 963, 965-66 (Sup. Ct. 1962); Hunter v. City of New York, 121 N.Y.S.2d 841 (Sup. Ct. 1953). In certain circumstances a landowner apparently can enjoin the local planning agency from proceeding with the plan in advance of condemnation proceedings. See Horton v. Redevelopment Comm'n, 259 N.C. 605, 131 S.E.2d 465 (1963) (use of ad valorem tax money for project before approval by taxpayers). But see City of Chicago v. R. Zwick Co., 188 N.E.2d 489, 491-92 (11l. 1963).

${ }_{72}$ See Shapiro v. Chicago Land Clearance Comm'n, 19 Ill. App. 2d 461, 154 N.E.2d 329 (1958). The theory seems to be that, in the absence of a statute, a landowner has no standing to sue.

${ }^{73}$ About half of the states now have "quick-taking" statutes. Sce Wasserman, supra note 6I, at 276. Only a few states, however, have authorized such a proceeding for urban renewal projects. See MinN. Stat. ANN. $\S 462.445$ (2) (Supp. 1962); N.J. Stat. ANN. § 20:1-36 (Supp. 1961); N.Y. MUNic. LAw § 506. Several other states have "quicktaking" statutes for higliway projects which could be simplified and adopted to urban renewal needs. See, e.g., ILL. ANN. STAT. ch. 47, § 2.1-9 (Smith-Hurd Supp. 1962); N.C. Gen. Stat. § 136-103 to -121 (Supp. 1961). Certainly the same reasons which prompted the widespread adoption of these statutes in the 1950's for highway pur. poses, the need of large tracts of land quickly and efficiently, applies equally as well to urban redevelopment and other urban renewal project purposes. 
agency early in a proceeding, would be highly desirable. Under the better version of such statutes, an agency can file a declaration of taking at any time after the institution of a condemnation proceeding; and, upon depositing the estimated compensation with the court, full title to the property vests in the agency. ${ }^{74}$ Besides eliminating the use of eminent domain proceedings as a bargaining weapon against the local planning agency, ${ }^{75}$ such a provision allows an agency maximum freedom in meeting redevelopment contract commitments. At the same time, the rights of contesting landowners are protected by their right to just compensation in eminent domain proceedings and the statute permitting court review of the planning features of a project. ${ }^{76}$

\section{CONGLUSION}

In order to acquire property for redevelopment and other urban renewal programs, a local planning agency must often make use of the power of eminent domain. If the agency is to meet its scheduled commitments, eminent domain proceedings need to be simple and expeditious. A delay in obtaining title to a particular tract may impede the progress of an entire project by causing the agency to forfeit on a redevelopment contract. ${ }^{77}$ Yet in most states these proceedings are so cumbersome and time-consuming that they needlessly inhibit an efficient land acquisition program.

Moreover, although the scope of judicial review in eminent domain proceedings is theoretically extremely narrow, there seems to be a growing trend for state courts to review carefully many of the determinations made in the planning stage of a project. The possibility of a decision invalidating one or more of these determinations in a proceeding brought months and possibly years after the

\footnotetext{
7t See, e.g., N.J. STAT. ANN. $\$ 20: 1-36$ (Supp. 1961). Some of the existing "quicktaking" statutes do not require the depositing of compensation before the taking. See N.Y. MUnic. LAw § 506, upheld in In re Baden-Ormond, 35 Misc. 2d 974, 231 N.Y.S.2d 679 (Sup. Ct. 1962). Such a statute would run into constitutional difficulties in many states. See Dodge, supra note 67, at 462; Wasserman, supra note 61, at 263-64, 275.

${ }^{75}$ See note 10 supra and accompanying text. In In re Baden-Ormond, supra note 74, the court summarily dismissed the landowner's contention that the "quick-taking" of his land was unconstitutional because it weakened his bargaining position with the local planning agency.

to "Quick-taking" statutes also give the judge discretion to delay the surrender of possession on a showing of hardship. See, e.g., Ilc. ANN. STAT. ch. 47, § 2.3 (b) (SmithFurd Supp. 1962). This protects a landowner who may need additional time to find a place to relocate his family or business.

"r See note 9 supra.
} 
project has been approved, makes the use of eminent domain for urban redevelopment projects even more hazardous.

As redevelopment projects become more complex and ambitious, expanded review of planning decisions in eminent domain proceedings shows indications of becoming more pronounced, particularly where a project includes industrial and commercial property and involves rehabilitation as well as slum and blight clearance. The traditional public purpose limitation on the power of eminent domain is, in effect, a dead-letter. ${ }^{78}$ Yet the danger of arbitrary action in the planning stage of a project is sufficiently great to justify careful scrutiny by a court of planning decisions; and, save for a few states, an eminent domain proceeding is the only effective forum wherein an aggrieved landowner is able to challenge the legality of a plan with respect to his property. ${ }^{79}$

Under these circumstances, the need for "quick-taking" provisions and a statute allowing an appeal to a court within a reasonable time after project approval would seem desirable. While effectively protecting the rights of aggrieved landowners, such reforms would also materially aid the local planning agency in acquiring project property by eminent domain more quickly and efficiently.

\footnotetext{
${ }^{78}$ See cases cited note 17 supra; Courtesy Sandwich Shop, Inc. v. Port of New York Authority, 190 N.E.2d 402, 407-11, 240 N.Y.S.2d 1, 9-15 (1963) (dissent); Dunham, Griggs v. Allegheny County In Perspective: Thirty Years of Supreme Court Expropriation Law, 1962 SUP. CT. REv. 63, 66-67, 106. In this connection, it is worth noting that the Supreme Court has never overruled a state court decision that a public improve. ment project was for a public purpose. See 2 Nichols $\$ 7.212(1)$.

${ }^{79}$ See note 72 supra. While it is true that an individual can challenge the plan in the required public hearings, there is much doubt as to tbe effectiveness of this remedy so far as the individual landowner's property is concerned. See Sullivan, Administrative Procedure and the Advocatory Process in Urban Redevelopment, 45 Calif. L. Rev. 134, 143-45 (1957); Note, 108 U. PA. L. Rev. 534, 569-86 (1960).
} 